\title{
Risk and injury portrayal in boys' and girls' favourite television programmes
}

$\mathrm{K}$ Pfeffer and J Orum

Inj. Prev. 2009;15;312-316

doi:10.1136/ip.2008.019539

Updated information and services can be found at:

http://injuryprevention.bmj.com/cgi/content/full/15/5/312

These include:

Data supplement

"Web only appendix"

http://injuryprevention.bmj.com/cgi/content/full/15/5/312/DC1

References This article cites 20 articles, 8 of which can be accessed free at: http://injuryprevention.bmj.com/cgi/content/full/15/5/312\#BIBL

Rapid responses You can respond to this article at: http://injuryprevention.bmj.com/cgi/eletter-submit/15/5/312

Email alerting Receive free email alerts when new articles cite this article - sign up in the box at service the top right corner of the article

Notes

To order reprints of this article go to:

http://journals.bmj.com/cgi/reprintform

To subscribe to Injury Prevention go to:

http://journals.bmj.com/subscriptions/ 


\title{
Risk and injury portrayal in boys' and girls' favourite television programmes
}

\author{
K Pfeffer, J Orum
}

\begin{abstract}
- An appendix is published online only at http:// injuryprevention.bmj.com/ content/vol15/issue5
\end{abstract}

Department of Psychology, University of Lincoln, Lincoln, UK

Correspondence to: Dr K Pfeffer, Department of Psychology, University of Lincoln, Lincoln LN6 7TS, UK; kpfeffer@lincoln.ac.uk

Accepted 4 March 2009

\author{
ABSTRACT \\ Objectives: To analyse the injury-related content of \\ children's television programmes preferred by boys and by \\ girls, and to determine whether there are more televised \\ models of unsafe behaviour in programmes preferred by \\ boys.
}

Methods: Parents of 4-11-year-old children identified their children's favourite television programmes. Content analysis of 120 episodes of children's favourite programmes was used to quantify safe and risky behaviours, actual injuries and potential injuries. The gender of the characters portraying the behaviours was also analysed. Results: More risky behaviour was portrayed in the boys' favourite programmes (mean per episode $=6.40$ ) than in the girls' favourite programmes (mean $=2.57)$. There were almost twice as many potential injuries $(n=310)$ as actual injuries $(n=157)$. Potential injuries were portrayed more often by male characters (mean $=1.92$ ) than female characters (mean $=0.98$ ), mostly in the boys' favourite programmes. Actual injuries occurred more often to male characters (mean $=1.04$ ) than to female characters (mean $=0.27$ ) overall.

Conclusions: Television programmes preferred by this sample of boys portrayed male role models engaging in risky behaviours and injuries more often than the programmes preferred by the sample of girls.

Unintentional injuries are a leading cause of death and disability to children between the ages 5 and 14 years. ${ }^{12}$ However, unintentional injuries are not equally distributed among children. One of the most commonly reported disparities is between boys and girls, with higher unintentional injury rates for boys than girls..$^{3-6}$

Possible reasons for this male predominance have not yet been thoroughly explained. There is growing evidence that boys and girls differ in their perception of risk, with boys rating dangerous activities as being less risky. ${ }^{78}$ Also, by the age of 6 years, children rate boys as having a lower risk of injury than girls, even though the actual injury rate for boys is higher than for girls."

Gender differences in socialisation practices may be one of several explanations for gender differences in risk perceptions and injury rates. Parents are usually the primary source of socialisation and provide the most readily available role models for their children. Children may also learn about safety, risk and injury through observing adults and other children indirectly. Television is a commonly available source of observational learning for children, especially those in high-income countries. Children may learn from televised portrayals of safe and risky behaviour by observing behaviour modelled by actors. Television has expanded the variety of models available to children and exposed them to a wide range of behaviours, many of which they may not otherwise have had the opportunity to observe.

Social cognitive theory ${ }^{10} 11$ explains how children learn vicariously from media sources. Children may learn new behaviours and the consequences (if any) of behaviours through television. Learned behaviours may be facilitated through observing televised behaviours, and beliefs about the consequences of behaviours may be internalised. ${ }^{12}{ }^{13}$ Although there have been many studies on the portrayal of violent behaviour on television and its potential effects on children, ${ }^{14}$ there are far fewer studies of the portrayal of safe and dangerous behaviours on television in relation to unintentional injuries. Studies of injury depiction in British television programmes are rare and mainly as a secondary consideration in studies of television violence. $^{15-17}$

Previous studies of portrayal of risky behaviour on TV have shown that risk is portrayed frequently ${ }^{18}$ and inaccurately ${ }^{19}$ in programmes and in advertisements. ${ }^{20}$ Glik et al ${ }^{19}$ found that risky behaviour was commonly depicted by characters in children's television programmes. Few of these characters suffered negative physical consequences as a result of risky behaviours or of being in dangerous environments. In contrast, behaviours that would normally result in injury in real life did not lead to injury for the television characters, and bystanders did not usually react to injurious behaviour. This reduced the severity or seriousness of danger. Glik et al also reported that safe behaviours were rarely depicted.

From the above studies, it is clear that television programmes viewed by children portray injuryproducing behaviours frequently and inaccurately. Although it has been suggested by researchers that boys are more exposed to televised unsafe behaviours, these studies did not compare the viewing preferences of boys and girls. The objectives of our study were (1) to analyse the injury-related content of children's television programmes preferred by boys and by girls and (2) to determine whether there are more televised models of unsafe behaviour in programmes preferred by boys.

\section{METHOD}

\section{Preliminary study}

Parents of 320 schoolchildren aged between 4 and 11 years were asked about their child's TV viewing preferences. The UK government report for the school the children attended stated that the economic context of the school was broadly average and the children's achievement was good. 
Table 1 Sample of programmes

\begin{tabular}{|c|c|c|c|}
\hline Type & Girls' favourites & Boys' favourites & $\begin{array}{l}\text { Girls' and boys' } \\
\text { favourites }\end{array}$ \\
\hline Live action & $\begin{array}{l}\text { Suite Life of Zach and } \\
\text { Cody } \\
\text { ChuckleVision } \\
\text { Zoey } 101\end{array}$ & $\begin{array}{l}\text { Power Rangers } \\
\text { Mr Bean }\end{array}$ & $\begin{array}{l}\text { Tracey Beaker* } \\
\text { Lazy Town } \\
\text { My Parents are Aliens }\end{array}$ \\
\hline Animation & $\begin{array}{l}\text { Bratz } \\
\text { Meg and Mog } \\
\text { Peppa Pig } \\
\text { Winx Club } \\
\text { Inspector Gadget }\end{array}$ & $\begin{array}{l}\text { Mona the Vampire* } \\
\text { Yu Gi Oh } \\
\text { Transformers } \\
\text { Bikermice from Mars } \\
\text { Sonic Underground } \\
\text { Pokemon }\end{array}$ & $\begin{array}{l}\text { The Simpsons } \\
\text { Fairly Odd Parents } \\
\text { SpongeBob } \\
\text { SquarePants } \\
\text { Scooby-Doo* } \\
\text { Tom and Jerry }\end{array}$ \\
\hline
\end{tabular}

*Programmes rated in the top 10 children's programmes by the weekly Broadcast publication in 2007 (www.broadcastnow.co.uk). Ratings for the remaining programmes were not available.

The sample was representative of British schoolchildren with respect to economic factors and scholastic achievement. All children present in school at the time of data collection were given a consent letter and questionnaire to take home to their parents. Questions concerned their child's age, gender and five favourite television programmes in rank order. Pre-paid envelopes were provided for questionnaires to be posted to the researcher anonymously. A total of 187 replies were received (58.4\%). There were 116 replies from parents with boys and 71 replies from parents with girls. The mean (SD) age of boys for whom completed questionnaires were returned was 6.79 (1.707) years and that for girls was $7.56(2.05)$ years. Questionnaire results were used to select a sample of TV programmes for analysis.

\section{Sample of TV programmes}

Popularity rankings obtained from the parental questionnaires were used to select 120 episodes from children's live and animated TV programmes. A total of 24 TV programmes were selected. Five episodes from each programme were sampled to obtain sufficient representation of behaviours within each of the programmes. All programmes were shown over a 2-month period in 2007.

The selection of programmes for analysis was organised into three groups identified from the parental questionnaires. The first and second groups comprised the eight most popular TV programmes for girls and the eight most popular TV programmes for boys (table 1). In addition, several programmes were popular among boys and girls; this formed a third group of eight most popular programmes for girls and boys. The complete sample consisted of 40 episodes per group. The mean (SD) programme length was 18.75 (7.07) $\mathrm{min}$, and the total media content analysed was $37.5 \mathrm{~h}$; credits and advertisements were not included. Although there were clear favourites identified by the older and younger children, there was also considerable overlap. Therefore it was decided not to analyse favourite programmes by age range for this relatively small sample of programmes.

The majority of programmes were animated. The percentage of live action programmes was $33.3 \%$ for the girls' favourite programmes, $22.2 \%$ for the boys' favourite programmes, and $33.3 \%$ for the programmes preferred by boys and girls. Imports from the USA, Canada, Japan and European countries made up $72.8 \%$ of the programmes and $28.2 \%$ were British made.

\section{Materials}

A checklist (based on Glik et $a l^{19}$ ) was used to quantify the number of times risky behaviours, injuries, potential injuries and safe behaviours occurred within each episode. Qualitative information about the events portrayed was also noted. For each behaviour and injury, the gender and age group (adult or child) of the person involved was coded (appendix 1 online).

The "safe behaviour" category included any actions that depict safe behaviour, eg wearing a cycle helmet, holding hands when crossing the street. "Risky behaviour" was defined as any behaviour that reflects consequences of a serious nature and that can result in either a potential or actual injury. "Actual injury" involved a description of the injury occurring, eg, head injury, scratches, burns. "Potential injury" was defined as any risky behaviour that has a high potential for causing injury (eg, falling, being hit with an object, crashing, fighting) but no injury is shown.

\section{Ethics}

The research was approved by the faculty ethics committee. The ethical code of conduct of the British Psychological Society was followed. Information for parents consisted of information about the nature of the research, assurances of anonymity, their right to withdraw from the research, and contact details of the researchers.

\section{Procedure}

All TV programmes were video-recorded or accessed online so that coders could rewind, re-view and pause the programmes. Two coders, blind to the gender-based category, independently viewed and coded episodes using the full checklist to establish coding reliability. After pilot studies, a high inter-coder agreement $(85.42 \%)$ was reached on the preliminary coding. Discrepancies between coders were discussed until 100\% agreement was reached. The full set of episodes was coded after establishment of full coder reliability.

The number of safe behaviours, risky behaviours, actual injuries and potential injuries per episode were compared across the three favourite TV programme groups: programmes preferred by girls, programmes preferred by boys, programmes preferred by girls and boys $(n=120)$. Also, comparisons were made between male and female characters using programmes that depicted humans and omitting those that portrayed animal, robot and other non-human characters $(n=85)$. Analysis of variance was used to make quantitative comparisons using SPSS V14. All post hoc analyses used Bonferroni corrections to avoid type 1 errors.

\section{RESULTS}

\section{Safe behaviours}

The mean number of safe behaviours per episode was low (fig 1) and there was no statistically significant difference between the favourite programme groups in amount of safe behaviour portrayed. Most of the safe behaviour was performed by adults (66.6\%).

\section{Risky behaviours}

More risky behaviour was portrayed in the boys' favourite programmes than in the other favourite programme groups (fig 1). Post hoc tests showed that more risky behaviour was portrayed in boys' favourite programmes than in girls' favourite programmes $(p<0.001, C I=99.9 \% 6.16$ to 1.48$)$. Also more risky behaviour was portrayed in boys' favourite programmes than in the girls' and boys' favourite programmes $(p<0.04$, $\mathrm{CI}=96 \% 0.08$ to 4.67$)$. However, there was no significant difference between girls' favourite programmes and girls' and boys' favourites. Most of the risky behaviour was performed by adults $(52.70 \%)$. 


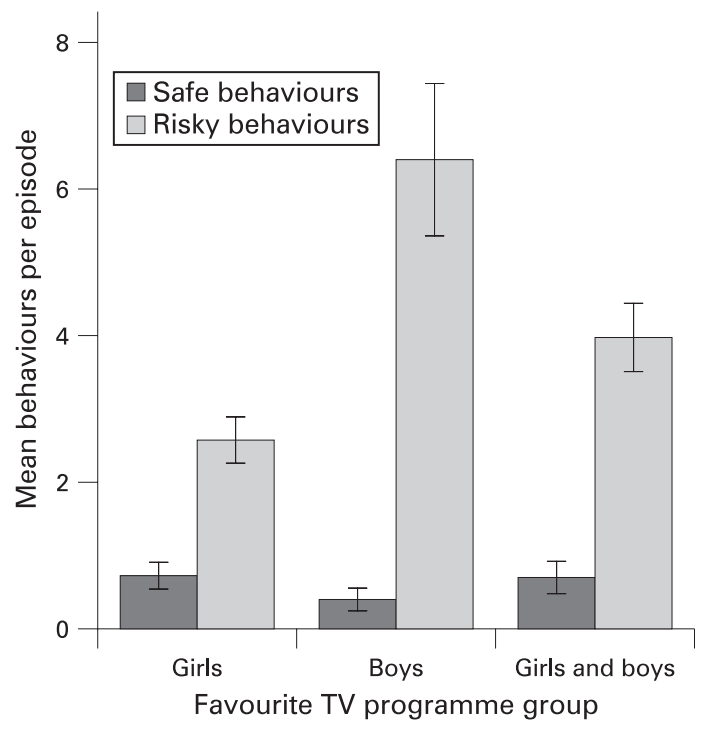

Figure 1 Comparison between mean number of safe and risky behaviours per episode for girls' favourite TV programmes, boys' favourite TV programmes and for girls' and boys' favourite TV programmes. Error bars indicate $\pm 1 \mathrm{SE}$. Safe behaviours: $F_{2,117}=0.92$, $\mathrm{p}>0.05$. Risky behaviours: $F_{2,117}=8.05, \mathrm{p}<0.001, \mathrm{Cl}=99.9 \%$.

\section{Injuries}

A total of 157 actual injuries were portrayed, with a significantly higher number of injuries portrayed in TV programmes preferred by boys (fig 2). Post hoc tests found more actual injuries were portrayed in boys' favourite programmes than in the other two groups $(p<0.001, \mathrm{CI}=99.9 \%$ 0.66 to 2.58 when compared with girls' favourite programmes and $\mathrm{p}<0.02, \mathrm{CI}=98 \% 0.16$ to 2.09 when compared with girls' and boys' favourite programmes). There was no significant difference between the girls' favourite programmes and the girls' and boys' favourite programmes.

There were almost twice as many potential injuries (310 in total) as actual injuries (157) (fig 2). In contrast with the portrayal of actual injuries, the number of potential injuries did not differ significantly across the three groups of TV programmes.

\section{Comparisons by gender of character}

For comparisons by gender of character, episodes with nonhuman characters were omitted from the analysis. There was no statistically significant difference between male and female characters in the number of safe behaviours performed per episode and no interaction between gender of character and programme group (fig $3 \mathrm{~A}$ ).

Male characters portrayed significantly more risky behaviours than female characters overall (fig 3B). There was also a significant interaction between gender of performer and programme group. More risky behaviours were portrayed by male characters in the favourite programmes for boys than the favourite programmes for girls $(p<0.001, C I=99.9 \% 2.35$ to $6.40)$ and the favourite programmes for girls and boys $(p<0.001$, $\mathrm{CI}=99.9 \% 1.38$ to 3.01 ). There was no significant difference in the amount of risky behaviour portrayed by female characters across the three favourite programme groups.

There were significantly more actual injuries per episode to male characters than to female characters (fig 4A). Post hoc analyses showed that the number of actual injuries to male characters was higher in the boys' favourite programmes than in

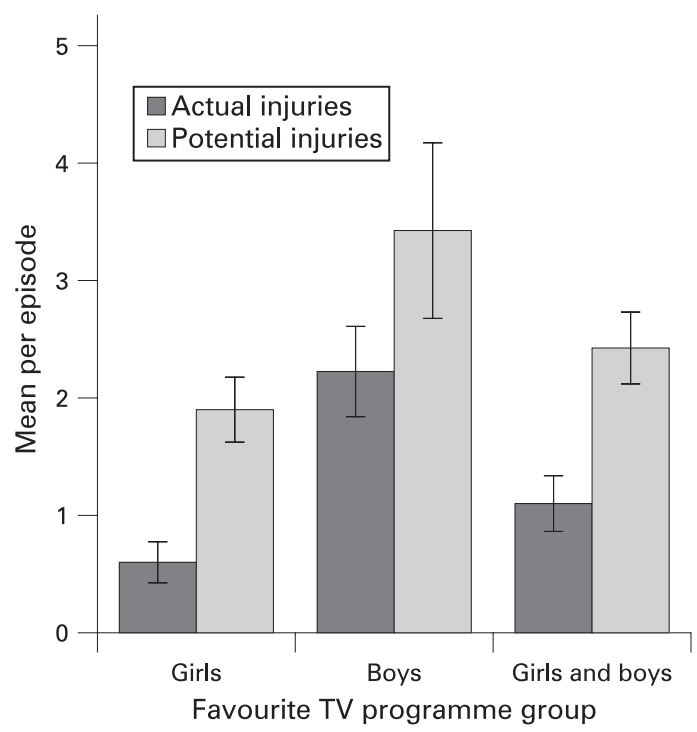

Figure 2 Comparison between mean number of actual injuries and potential injuries per episode for girls' favourite TV programmes, boys' favourite TV programmes and girls' and boys' favourite TV programmes. Error bars indicate \pm 1 SE. Actual injuries: $F_{2,117}=8.85, \mathrm{p}<0.001$, $\mathrm{Cl}=99.9 \%$. Potential injuries: $F_{2,117}=2.47, \mathrm{p}>0.05$.

the girls' favourite programmes $(\mathrm{p}<0.001, \mathrm{CI}=99.9 \% 1.07$ to $2.78)$ and the favourite programmes for girls and boys $(p<0.001$, $\mathrm{CI}=99.9 \% 0.97$ to 2.68 ). There was no significant difference in the amount of actual injury portrayed by female characters across the three favourite programme groups.

There were more potential injuries to male characters than female characters overall (fig 4B). Post hoc tests showed more potential injuries for male characters in the boys' favourite programmes than in the girls' favourites ( $<<0.02, \mathrm{CI}=98.0 \%$ 0.18 to 3.19 ). There were no significant differences in the amount of potential injury portrayed by female characters across the three programme groups.

\section{Presence and actions of bystanders}

Although bystanders were often portrayed at the scene of an actual or potential injury event $(90.10 \%$ of the time), in most cases $(72.5 \%)$ they gave no help. There was no significant difference in the amount of help given to male and female characters.

\section{DISCUSSION}

The results indicate that television programmes preferred by our sample of boys portrayed risky behaviours more often than the programmes preferred by our sample of girls. Programmes preferred by boys also portrayed more injuries. The characters portraying more risky behaviour, actual injuries and potential injuries were predominantly male. These results support previous findings ${ }^{19}$ that male characters were more likely to portray injury than female characters in children's television programmes.

The results were consistent with those of previous research$\operatorname{ers}^{19}{ }^{21}$ in that risky behaviours were often portrayed across all favourite programme groups. There were more potential injuries than actual injuries overall. Although bystander characters were present during the injury events, they rarely rendered help. Safe behaviours were less often portrayed, and there were no gender differences in amount of safe behaviours shown. Overall, television programmes enjoyed by children 
Figure 3 (A) Mean number of safe behaviours per episode portrayed by male and female characters. Error bars indicate \pm 1 SE. Gender comparison: $F_{1,82}=1.96$, $\mathrm{p}>0.05$. Interaction between gender and programme group: $F_{2,82}=0.58, \mathrm{p}>0.05$. (B) Mean number of risky behaviours per episode portrayed by male and female characters. Gender comparison: $F_{1,82}=38.61, \mathrm{p}<0.001, \mathrm{Cl}=99.9 \%$. Interaction between gender and programme group: $F_{2,82}=11.31$, $\mathrm{p}<0.001, \mathrm{Cl}=99.9 \%$.
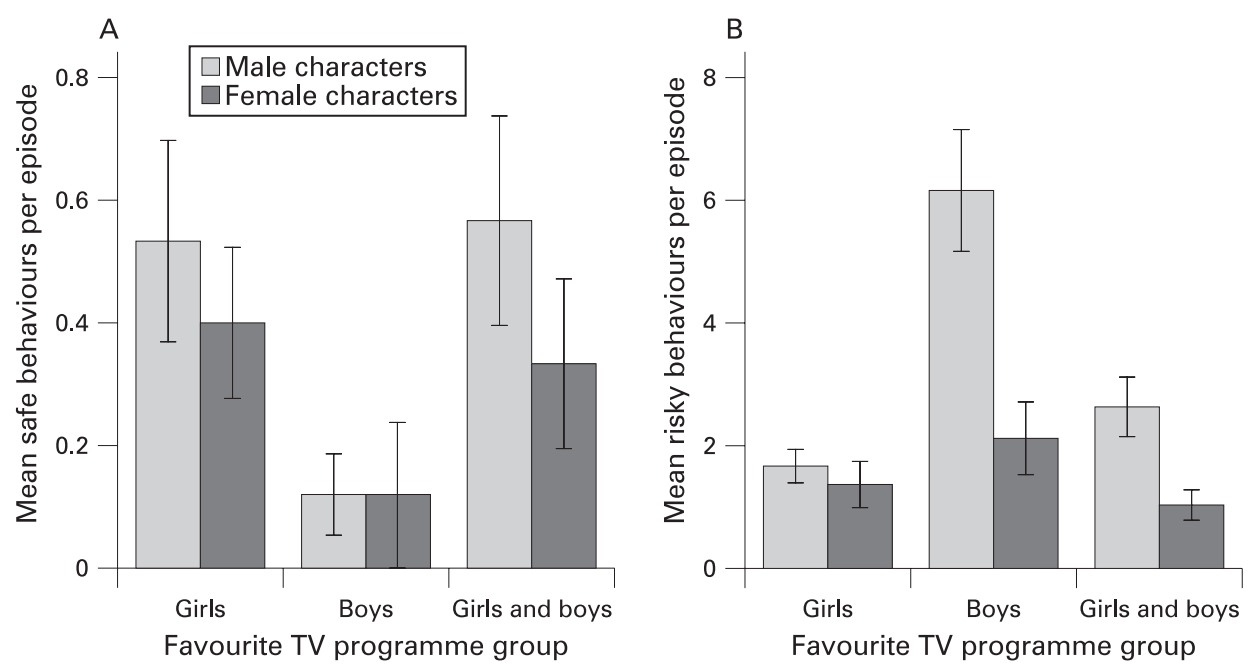

continue to model risky behaviour and portray injury inaccurately.

Much of the risky behaviour being modelled was inaccurately depicted as potential injury-that is, having no injurious consequences. For example, live action programmes included characters slipping, falling from a height and being hit by objects without being hurt. Male characters were also shown climbing a building using a damaged rope or a loose drainpipe with no adverse effects. With reference to social cognitive theory, televised characters provide sources of learning new risky behaviours for children and may reinforce such learning by portraying few if any negative consequences of risky behaviour. In addition, most risky behaviours were performed by male characters (mostly men), providing the most appropriate role models for boys. More risky behaviour, actual injury and potential injury were portrayed by male characters in the programmes preferred by boys.

Socialisation of risky behaviour involves more than watching television programmes. It would be too simplistic to assume that boys take more risks than girls because they view more televised risk. Boys may prefer programmes portraying more risks because they provide more excitement. Also, not all that is observed on television or elsewhere will be learned or modelled, and children do not necessarily absorb television messages passively. $^{22}$

However, there is convincing evidence that televised risky behaviour can and does affect children's risk-taking. ${ }^{23}$ Children have been reported to imitate popular stunt-riders ${ }^{24}$ and wrestlers. ${ }^{25}$ Also, Potts et al ${ }^{23}$ found that 6-9-year-old children who viewed risk-taking behaviour on television showed an increase in risk-taking. Potts and Swisher ${ }^{26}$ found that the televised portrayal of safety models to 5-8-year-old children decreased their willingness to take physical risks and increased their ability to identify hazards. Although boys had higher levels of risk-taking overall in these two studies, ${ }^{23}{ }^{26}$ boys and girls were equally affected by both risky and safe television content. The authors concluded that boys are not more influenced than girls by televised portrayals of risk. They proposed that boys may be more exposed to televised portrayals of risk than girls. This increased exposure may amplify already existing gender differences in risk-taking.

The main limitations of this study are that the sample size of 120 episodes is small in comparison with some previous studies. Also, the comparison of boys' favourite programmes with girls' favourite programmes was based on reports from a small sample of 187 parents. As children's favourite television programmes
Figure 4 (A) Mean number of actual injuries per episode portrayed by male and female characters. Error bars indicate \pm 1 SE. Gender comparison:

$F_{1,82}=38.70, \mathrm{p}<0.001, \mathrm{Cl}=99.9 \%$. Interaction between gender of character and programme group: $F_{2,82}=14.09$, $\mathrm{p}<0.001, \mathrm{Cl}=99.9 \%$. (B) Mean number of potential injuries per episode portrayed by male and female characters. Gender comparison: $F_{1,82}=19.82, \mathrm{p}<0.001$, $\mathrm{Cl}=99.9 \%$. Interaction between gender of character and programme group: $F_{2,82}=3.60, \mathrm{p}>0.05$.
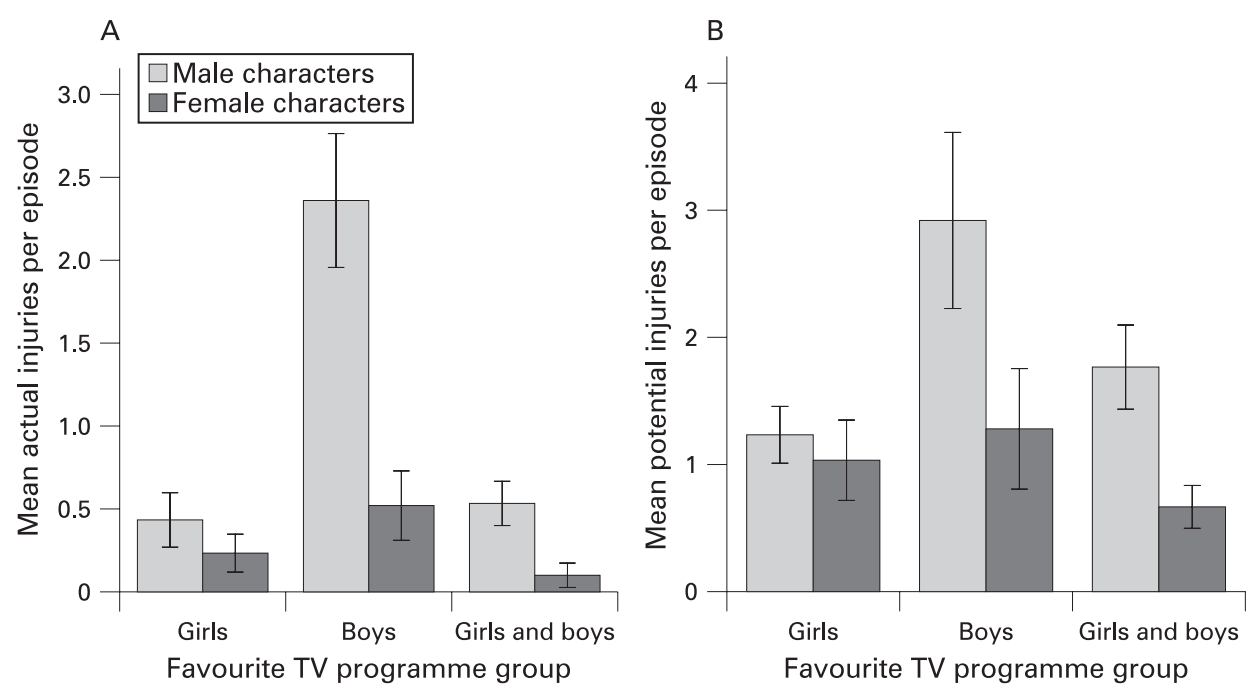

Favourite TV programme group 


\section{What is already known on this subject}

- Boys have higher injury rates than girls.

- Children's television programmes portray injury risk frequently and inaccurately.

- The portrayal of risky behaviour on TV can influence some children's behaviour.

\section{What this study adds}

- Boys' favourite TV programmes portray risk and injury more often than girls' favourite TV programmes.

- Male TV characters portray risk and injury more often than female TV characters.

- British children's television programmes portray risky behaviours inaccurately.

may change over time, further studies are needed to determine the generalisability of our findings. However, our study is one of the first to directly compare the television viewing choices of boys and girls in relation to injury portrayal. Also, it is one of the few studies of unintentional injury portrayal in UK children's television programmes. The method used cannot determine the extent to which children's injury rates are influenced by modelling the unsafe behaviour of television characters. Therefore further research is needed into the relationship between television viewing and child injury rates as well as the effect of repeatedly showing unsafe behaviour with no injurious consequences.

Unfortunately, risky behaviour on television is more effective in attracting young viewers ${ }^{27}$ so it is unlikely to be reduced in children's television content. However, parents could take the opportunity to discuss the contrasts between risk-taking on television and in real life. This is particularly important for younger children, as those aged less than 8 years often have difficulties in making a distinction between fantasy and reality in television programmes. ${ }^{28}$

Our findings may be helpful to parents in influencing their children's programme choices. Some programmes (eg, Power Rangers) showed considerably more risky behaviours than others. Programme ratings for risky behaviour would help parents to make informed decisions about their children's television viewing. For health educators, it may be important to include information about the media depictions of injury risk in their safety education information and training. The amount of television children watch has been found to be higher in households where children have a TV in their bedroom and where parents do not set specific rules for TV viewing. ${ }^{29}$ Health professionals should inform parents of the potentially higher risk of unintentional injury to boys and consider encouraging parents to limit children's television viewing, especially unsupervised viewing in children's bedrooms.
Competing interests: None.

Ethics approval: Obtained.

Provenance and peer review: Not commissioned; externally peer reviewed.

\section{REFERENCES}

1. UNICEF. A league table of child deaths by injury in rich nations. Innocenti Report Card No 2. Florence: UNICEF Innocenti Research Centre, 2001.

2. World Health Organization. World report on road traffic injury prevention: summary. Geneva: WHO, 2004.

3. Department for Transport. Child road safety: achieving the 2010 target. London: Department for Transport, 2002.

4. Roberts H. Child accidents at home, school and play. In: Gillham B, Thomson JA, eds. Child safety: problem and prevention from preschool to adolescence. London: Routledge, 1996:55-66.

5. Rosen N, Peterson L. Gender differences in children's outdoor play injuries: a review and an integration. Clin Psychol Rev 1990;10:187-205.

6. Towner E, Dowswell T, Errington G, et al. Injuries in children aged 0-14 years and inequalities. London: NHS Health Development Agency, 2005.

7. Hillier LM, Morrongiello BA. Age and gender differences in school-age children's appraisals of injury risk. J Pediatr Psychol 1998;23:229-38.

8. Schwebel DC, Barton BK. Contributions of multiple risk factors to child injury. J Pediatr Psychol 2005;30:553-61.

9. Morrongiello BA, Midgett C, Stanton K. Gender biases in children's appraisals of injury risk and other children's risk-taking behaviors. J Exp Child Psychol 2000;77:317-36.

10. Bandura A. Social cognitive theory of mass communication. In: Bryant A, Zillman D, eds. Media effects: advances in theory and research. Mahwah, NJ: Lawrence Erlbaum, 2002:121-54.

11. Bandura A. Social foundations of thought and action: a social cognitive theory. Englewood Cliffs, NJ: Prentice-Hall Inc, 1986.

12. DiLillo D, Potts R, Himes S. Predictors of children's risk appraisals. J App/ Dev Psychol 1998;19:415-27.

13. Will KE, Geller ES, Porter BE, et al. Is television a health and safety hazard? A crosssectional analysis of at-risk behavior on primetime television. J Appl Soc Psychol 2005;35:198-222.

14. Anderson $\mathbf{J}$. The production of media violence and aggression research: a cultural analysis. Am Behav Sci 2008;51:1260-79.

15. Gunter B, Harrison J. Violence in children's programmes on British Television. Children \& Society 1997;11:143-56.

16. Gunter B. Ethnicity and involvement in violence on television: nature and context of onscreen portrayals. J Black Stud 1998;28:683-703.

17. Potter WJ, Vaughan MW, Warren R, et al. How real is the portrayal of aggression in television entertainment programming? Journal of Broadcasting \& Electronic Media 1995;39:496-516.

18. Winston FK, Woolf KD, Jordan A, et al. Actions without consequences: injury-related messages in children's programs. Arch Pediatr Adolesc Med 2000;154:400-3.

19. Glik D, Kinsler J, Todd WA, et al. Unintentional injury depictions in popular children's television programs. Inj Prev 2005;11:237-41.

20. Tamburro Robert F, Gordon Patricia L, D'Apolito James P, et al. Unsafe and violent behavior in commercials aired during televised major sporting events. Pediatrics 2004; 114:e694-8.

21. Potts R, Henderson J. The dangerous world of television: a content analysis of physical injuries in children's television programming. Children's Environments 1991;8:7-14.

22. Durkin K. Myers, media and modern times. Psychologist 2007;20:26-9.

23. Potts R, Doppler M, Hernandez M. Effects of television content on physical risktaking in children. J Exp Child Psychol 1994;58:321-31.

24. Daven F, O'Conner J, Briggs R. The consequences of imitative behavior in children: the "Evel Knievel syndrome". Pediatrics 1976;57:418-19.

25. Lemish D. The school as wrestling arena: the modelling of a television series Communication 1997;22:395-418.

26. Potts R, Swisher L. Effects of televised safety models on children's risk taking and hazard identification. J Pediatr Psychol 1998;23:157-63.

27. Potts R, Huston AC, Wright JC. The effects of television form and violent content on boys' attention and social behavior. J Exp Child Psychol 1986;41:1-17.

28. Gunter B, McAleen JL. Children and television: the one-eyed monster? London: Routledge, 1990.

29. Roberts DF, Foehr UG, Rideout V. Generation M: media in the lives of 8-18 yearolds. The Henry J Kaiser Family Foundation: 2005. www.kff.org/entmedia/7251.cfm (accessed 29 Apr 2009). 